\title{
Geochemical Tracer in Coral as a Sea Surface Temperature Proxy: Records from Jukung Coral
}

\author{
S.Y. Cahyarini ${ }^{1} \&$ J. Zinke ${ }^{2}$ \\ ${ }^{1}$ Puslit Geoteknologi LIPI, Bandung, Indonesia \\ ${ }^{2}$ Dept. Paleoclim. \& Paleoecology Vrije Universiteit Amsterdam, The Netherlands
}

\begin{abstract}
Sr/Ca has been analyzed from coral core from the Seribu Islands reef complex i.e Jukung Island. SST from ERSST dataset and air temperature measured at Jakarta is used for $\mathrm{Sr} / \mathrm{Ca}$ calibration. The results show that Jukung Island coral $\mathrm{Sr} / \mathrm{Ca}$ correlates better with $\mathrm{SST}$ than with air temperature. A comparison between the $\mathrm{Sr} / \mathrm{Ca}$ records with the Nino 3.4 index shows that Jukung coral sites indicate warming sea surface temperatures during the beginning of El Nino events followed by cooling temperatures at the end of El Nino years.
\end{abstract}

Keywords: corals; El Nino; Sr/Ca; SST.

\section{$1 \quad$ Introduction}

Sea surface temperature (SSTs) is one of the most important climatic parameters. The instrumental SST dataset available is rarely covered till back hundreds to thousand years. Geochemical proxy data (e.g. content in coral, sediment etc) overcome this problem. Many previous studies show that $\mathrm{Sr} / \mathrm{Ca}$ content in corals is a promising temperature proxy (e.g. [1]; [2]; [3]). It is believed that $\mathrm{Sr} / \mathrm{Ca}$ is influenced by SST only. The ratio of the incorporation of $\mathrm{Sr}$ to $\mathrm{Ca}$ is controlled by two factors: (1) The $\mathrm{Sr} / \mathrm{Ca}$ activity of the ocean water, (2) the $\mathrm{Sr} / \mathrm{Ca}$ distribution coefficient between aragonite and seawater. When a compatible trace component substitutes for lattice calcium in aragonite (a guest/host substitution) the concentration of that trace element can be predicted by its distribution coefficient $\left(\mathrm{D}_{S r}\right)$ :

$$
D_{s r}=\frac{[\mathrm{Sr}] /[\mathrm{Ca}]_{\text {coral }}}{[\mathrm{Sr}] /[\mathrm{Ca}]_{\text {seawater }}}
$$

The distribution coefficient strongly depends on the temperature of the seawater where the coral grows $[4,5]$. Several studies confirm that the value of $\mathrm{D}_{S r}$ has remained constant (e.g [6]; [7]). The $\mathrm{Sr} / \mathrm{Ca}$ ratios of seawater are constant. Thus, variations of the distribution coefficient, and hence variations in coral $\mathrm{Sr} / \mathrm{Ca}$, are determined by ambient water temperature. Thus, coral $\mathrm{Sr} / \mathrm{Ca}$ can be used to reconstruct temperature. 
Linear regression analysis of $\mathrm{Sr} / \mathrm{Ca}$ measurements against SST is commonly applied to quantify the coral $\mathrm{Sr} / \mathrm{Ca}$ - SST relationship (e.g. [8]; [9], [10]). Ideally, one should use a continuous time series of SST directly from the site where the coral grew. However, the limited local SST measurements available have forced most studies to use grid-SST from various sources.

In this study $\mathrm{Sr} / \mathrm{Ca}$ ratios of corals from the Seribu Islands reef complex i.e. Jukung Island is analyzed. $\mathrm{Sr} / \mathrm{Ca}$ is calibrated with SST from Extended Reconstructed Sea Surface Temperature (ERSST) dataset [11,12] and air temperature measured at Jakarta station. The hypothesis of this study is that the offshore Jukung corals will correlate with the sea surface temperature in seasonal scale.

\section{$2 \quad$ Material and Method}

\subsection{Corals}

Massive Porites coral cores were drilled across the Seribu Islands reef complex, i.e Jukung, Island (S 5³4'01', E 106 ${ }^{\circ} 31^{\prime} 38^{\prime \prime}$ ) in September 2005. The coral was drilled vertically. The Jukung (JU) Island core is $2.23 \mathrm{~m}$ in length and was drilled at $2 \mathrm{~m}$ depth. A pneumatic drill powered by scuba air pressure is used in this study. The drill bit is a diamond-tipped steel tube $3.6 \mathrm{~cm}$ in diameter and $30 \mathrm{~cm}$ long. By using extension rods of $1 \mathrm{~m}$ length, it is possible to recover cores of up to $5 \mathrm{~m}$ in length [13].

Coral core was cut in a thickness of $4 \mathrm{~mm}$. Slabs were rinsed several times in an ultrasonic bath for about 15 minutes and dried with compressed air after each step. The clean slabs were dried overnight at $40^{\circ} \mathrm{C}$ and X-rayed using $35 \mathrm{kvp}$ for 12 minutes to reveal the annual banding. Slabs were subsampled manually using a hand-held drill with a drilling bit of $1 \mathrm{~mm}$ along the growth axis at \pm 1 $\mathrm{mm}$ interval to get a monthly resolution. The sample powders were splitted for $\mathrm{Sr} / \mathrm{Ca}$ and other geochemical analysis.

\subsection{Historical data: Sea Surface Temperature (SST) and Air Temperature (AT)}

In this study historical data such as sea surface temperature (SST) and air Temperature (AT) is used for calibration. SST data is obtained from Extended Reconstructed Sea Surface Temperature (ERSST) database version 2 [11,12]. The ERSST dataset is available for the period 1854 till the present time. The local measurements of air temperature at Jakarta weather station is used in this study (from June 1992 to September 2005) which is obtained from Badan Meteorologi, Klimatologi dan Geofisika (BMKG). Figure 1 shows both dataset 
for the period 1992-2005. The Extended Reconstructed Sea Surface Temperature (ERSST) data are averaged over a grid of $5^{\circ}-6^{\circ} \mathrm{S}, 105^{\circ}-106^{\circ} \mathrm{E}$.

\subsection{Sr/Ca Preparation and Analysis Method}

$\mathrm{Sr} / \mathrm{Ca}$ ratios are measured in an Inductively Coupled Plasma Optical Emission Spectro-photometer (ICP-OES) at the Geological Institute of the University of Kiel following a combination of the techniques described in detail by [14] and [15]. The $\sim 0.5 \mathrm{mg}$ coral powder is dissolved in $1 \mathrm{ml} \mathrm{HNO}_{3} 2 \%$. The working solutions were prepared by a serial dilution of the sample solution with $\mathrm{HNO}_{3}$ $2 \%$ to get a concentration of about $8 \mathrm{ppm} \mathrm{Ca}$. The standard solution was prepared by dilution of $1 \mathrm{ml}$ from a stock solution ( 0.52 gram of coral powder from a Mayotte coral in $250 \mathrm{ml} \mathrm{HNO}_{3} 2 \%$ with $2 \mathrm{ml} \mathrm{HNO}_{3} 2 \%$ ). The relative standard deviation (RSD) of multiple measurements on the same day and on different days is about $\pm 0.15 \%$.In this session $\mathrm{Sr} / \mathrm{Ca}$ of the coral core tops and 272 powder samples at $2 \mathrm{~mm}$ resolution is analyzed.

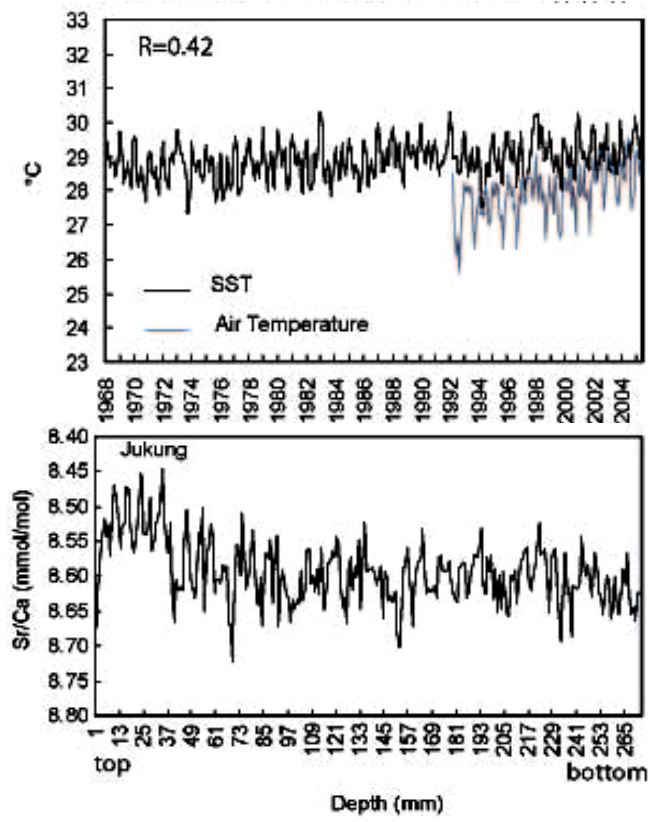

Figure 1 (Top) Monthly variation of sea surface temperature (source ERSST dataset) and air temperature (source BMG). (bottom) Measured $\mathrm{Sr} / \mathrm{Ca}$ from Jukung coral in monthly resolution.

\subsection{Chronology Development Method}

The preliminary chronology was developed using the annual density banding observed in the X-Ray's. A monthly resolved time series using the anchor point 
method by assigning the minima and maxima in coral $\mathrm{Sr} / \mathrm{Ca}$ to maxima and minima in SST, respectively (e.g. [3]) is developed. The uncertainty of the chronology development based on the anchor point method is about 1-2 months in any given year. The result of the chronology development based on $\mathrm{Sr} / \mathrm{Ca}$ measurements is result in 1968 to 2005 time window (see [16]).

\section{Sea Surface Temperature at Seribu Islands Waters}

Based on the monthly mean SST for the grid-box covering the Seribu Islands (average of grid $5-6^{\circ} \mathrm{S}, 105-106^{\circ} \mathrm{E}$ ) two warming peaks are observed in this region i.e. in May and November. The warmer temperature is about $29.61^{\circ} \mathrm{C}$ (May) and $28.98^{\circ} \mathrm{C}$ (November). The coolest SST is observed in February $\left(28.59^{\circ} \mathrm{C}\right)$ and September $\left(28.20^{\circ} \mathrm{C}\right)$.

\section{$4 \quad$ Results and Discussions}

\subsection{Historical data}

Comparison between SST (ERSST) averaged for the grid between $5^{\circ} \mathrm{S}-6^{\circ} \mathrm{S}$, $105^{\circ} \mathrm{E}-106^{\circ} \mathrm{E}$ with single SST (ERSST) datasets from Jukung Island coordinates does not show significant differences. However, the correlation of ERSST with air temperature measured at Jakarta is low $(\mathrm{R}=0.42)$. Both air temperature and ERSST is used for calibration with coral $\mathrm{Sr} / \mathrm{Ca}$ records.

\subsection{Coral Chronology}

Based on chronology using anchor point method, where minimum/maximum coral $\mathrm{Sr} / \mathrm{Ca}$ is matched with the maximum/minimum SST it is obtained a time window covering May 1968 to September 2005 (Figure 2).

\subsection{Sr/Ca vs. Sea Surface Temperature Calibration}

The result of $\mathrm{Sr} / \mathrm{Ca}$ analysis shows the seasonal variation of $\mathrm{Sr} / \mathrm{Ca}$ (Figure 1). The average value of the $\mathrm{Sr} / \mathrm{Ca}$ ratios is $8.593 \mathrm{mmol} / \mathrm{mol}$. Table 1 shows statistics for $\mathrm{Sr} / \mathrm{Ca}$ content in Jukung Island coral.

Coral $\mathrm{Sr} / \mathrm{Ca}$ is calibrated with temperature using linear regression. Decreasing coral $\mathrm{Sr} / \mathrm{Ca}$ corresponds to increasing temperature. Calibration of $\mathrm{Sr} / \mathrm{Ca}$ from the Jukung Island record (further mention $\mathrm{Sr} / \mathrm{Ca}_{J u}$ ) shows a good correlation with ERSST $(\mathrm{R}=0.53)$ and lower correlation with air temperature $(\mathrm{R}=0.39)$. The regression slope of $\mathrm{Sr} / \mathrm{Ca}_{J}$ vs ERSST is $0.05 \mathrm{mmol} / \mathrm{mol} /{ }^{\circ} \mathrm{C}$. For the whole period of the Jukung coral i.e. 1968-2005 the correlation coefficient of $\mathrm{Sr} / \mathrm{Ca}_{J u}$ vs ERSST is $\mathrm{R}=0.49$, the regression slope is $0.04 \mathrm{mmol} / \mathrm{mol} /{ }^{\circ} \mathrm{C}$. The calibration slope of Jukung $\mathrm{Sr} / \mathrm{Ca}$ records is in the range of calibration slopes 
reported for $\mathrm{Sr} / \mathrm{Ca}$ vs temperature in the literature (i.e. $-0.04--0.08$ $\left.\mathrm{mmol} / \mathrm{mol} /{ }^{\circ} \mathrm{C},[5] ;[2,15] ;[17] ;[18] ;[7] ;[19]\right)$.

Table 1 Descriptive statistics of Jukung coral Sr/Ca analysis.

\begin{tabular}{lc}
\hline \multicolumn{2}{c}{ Descriptive Statistic } \\
\hline Mean & 8.593 \\
Standard Deviation & 0.047 \\
Minimum & 8.446 \\
Maximum & 8.723 \\
Count & 272 \\
\hline
\end{tabular}
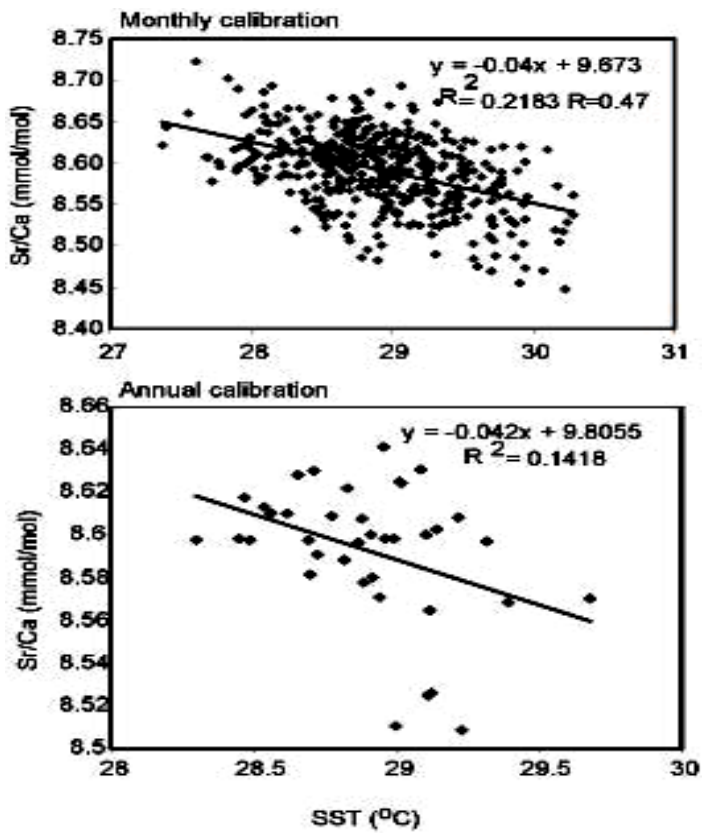

Figure 2 Calibration of Sr/Ca and SST in (Top) monthly and (Bottom) annual mean scale.

In the annual mean calibration the correlation between $\mathrm{Sr} / \mathrm{Ca}_{J u}$ with SST is low $\mathrm{R}=0.37$, however the calibration slope $\left(-0.042 \mathrm{mmol} / \mathrm{mol} /{ }^{\circ} \mathrm{C}\right)$ is in the range of the agreement slope for Sr/Ca vs. SST.

Based on the calibration results, it is suggested that the corals from Jukung Island record SST clearly in seasonal and annual mean scale. Figure 2 shows calibration chart of $\mathrm{Sr} / \mathrm{Ca}$ vs. SST. 


\subsection{Sr/Ca signal during El Nino years}

ENSO is the climate phenomena, which is characterized by the SST gradient anomaly between eastern and western Pacific. This climate phenomena has global influence around the world including Indonesia. The El Nino 1997/98 cause mortality of the Seribu corals due to bleaching [20]. To indicate the influenced of ENSO event in the Seribu waters region till back to $40 \mathrm{yrs}$, the coral $\mathrm{Sr} / \mathrm{Ca}_{\mathrm{Ju}}$ is correlated with the Nino 3.4 index. The result is shown in Figure 4. The high negative correlation between $\mathrm{Sr} / \mathrm{Ca}_{\mathrm{Ju}}$ and Nino 3.4 index is found during boreal winter. This indicates that during the El Nino event which is strong during the boreal winter the Seribu Islands waters show decreasing temperature while increasing temperature shown in the eastern Pacific characterized (Figure 3).

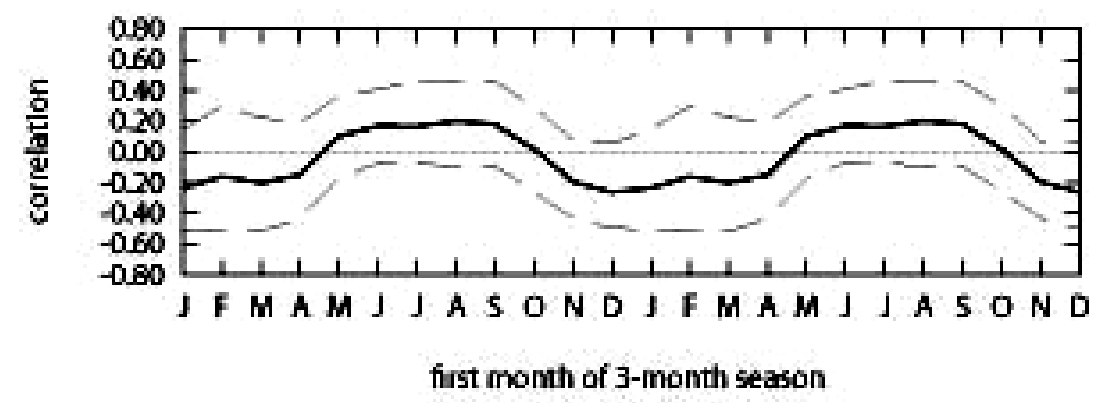

Figure 3 Correlation between $\mathrm{Sr} / \mathrm{Ca}$ and Nino 3.4 index in 3 month seasonal average.

\section{Summary}

The $\mathrm{Sr} / \mathrm{Ca}$ from the core tops of corals from the Seribu Islands reef complex shows correlation with sea surface temperature. A correlation with the El Niño events which shows high negative correlation between coral $\mathrm{Sr} / \mathrm{Ca}$ and the Nino 3.4 index during boreal winter is observed. The correlation is changes from one season to another season. Longer records of $\mathrm{Sr} / \mathrm{Ca}$ coral are still required to understand the long-term history of SST changes across the Seribu island reef complex and to improve statistical time series analysis. Besides, analysis of longer proxy records which represent the inshore to offshore corals from Seribu islands is required to more understand the impact of the Jakarta coastal city to the ocean waters ecosystem in the Jakarta bay.

\section{Acknowledgements}

We acknowledge funding through the Koninklijke Nederlandse Akademie van Wetenschappen (KNAW-SPIN) and International Foundation of Sciences (IFS) 
grant no A4605-1 for SYC. The project was also supported by the LIPI Competitive Research Grant 2007 No: 11.03/SK/KPPI/ /2007 for SYC. Thank to Dudi Prayudi, Samsuardi, Yayat Sudrajat for their assistant during the field work at the Seribu islands. Thanks to the reviewers for their comments which improve this manuscript.

\section{References}

[1] McCulloch, M.T., Gagan, M.K. , Mortimer, G.E., Chivas, A.R. \& Isdale P.J., A high-resolution $\mathrm{Sr} / \mathrm{Ca}$ and $\delta^{18} \mathrm{O}$ coral record from the great barrier reef, Australia and the 1982-1983 El Niño, Geochimica et Cosmochimica Acta, 58, 2747-2754, 1994.

[2] de Villiers, S., Shen, G.T. \& Nelson B.K., The Sr/Ca temperature relationship in coralline aragonite: Influence of variability in $(\mathrm{Sr} / \mathrm{Ca})$ seawater and skeleton growth parameters, Geochimica et Cosmochimica Acta, 58, 197-208, 1994.

[3] Cahyarini, S.Y., Pfeiffer, M., Timm, O., Dullo, W-C. \& Schönberg, D.G., Reconstructing seawater $\delta^{18} \mathrm{O}$ from paired coral $\delta^{18} \mathrm{O}$ and $\mathrm{Sr} / \mathrm{Ca}$ ratios: Methods, error analysis and problems, with examples from Tahiti (French Polynesia) and Timor (Indonesia), Geochimica et Cosmochimica Acta, 72(12), 2841-2853, 2008.

[4] Kinsman, D.J.J \& Holland, H.D, The co-precipitation of cations with $\mathrm{CaCO}$. The co-precipitation of $\mathrm{Sr} 2+$ with aragonite between $16^{\circ}$ and $96^{\circ} \mathrm{C}$ Geochimica et Cosmochimica Acta, 33 (1), 1-17, 1969.

[5] Beck, W.J., Edwards, L.R., Ito, E., Taylor, F.W., Recy, J., Rougerie, F., Joannot, P. \& Henin, C., Sea surface temperature from coral skeleton Sr/Ca ratios, Science, 257, 644-647, 1992.

[6] Weber, J.N., Incorporation of strontium into reef coral skeletal carbonate, Geochimica et Cosmochimica Acta, 37, 2173-2190, 1973.

[7] Marshall, J.F. \& McCulloch, M.T.,An assessment of the Sr/Ca ratio in shallow water hermatypic corals as a proxy for sea surface temperature, Geochimica et Cosmochimica Acta, 66, 3263-3280, 2002.

[8] Gagan, M.K., Ayliffe, L.K., Hopley, D., Cali, J.A., Mortimer, G.E., Chappel, J., McCulloch, M.T. \& Head M. J., Temperature and surface ocean water balance of mid-Holocene tropical western pacific, Science, 279, 1014-1018, 1998.

[9] Linsley, B.K., Wellington, G.M. \& Schrag D.F., Decadal sea surface temperature variability in the subtropical south Pacific from 1726 to 1997 AD, Science, 290, 1145-1148, 2000.

[10] Linsley, B.K., Wellington, G.M., Schrag, D.P., Ren, L., Salinger, M.J. \& Tudhope, A.W., Geochemical evidence from corals for changes in the amplitude and spatial pattern of south Pacific interdecadal climate 
variability over the last 300 years, Climate Dynamics, 22(1), doi :10.1007/s00382-003-0364-y, 2004.

[11] Smith, T.M. \& Reynolds R.W., Improved Extended Reconstruction of SST (1854-1997), Journal of Climate, 17, 2466-2477, 2004.

[12] Smith, T.M., Reynolds, R.W., Peterson, T.C. \& Lawrimore J., Improvements to NOAA's Historical Merged Land-Ocean Surface Temperature Analysis (1880-2006), In press. J. Clim., 2007.

[13] Heiss, G.A. \& Dullo, W.-Chr., Stable isotope record from recent and fossil Porites sp. in the northern Read Sea, Coral Research Bulletin, 5, 161-169, 1994.

[14] Schrag, D.P., Rapid analysis of high-precision Sr/Ca ratio in corals and other marine carbonates, Paleoceanography, 14, 97-102, 1999.

[15] de Villiers, S., Greaves, M. \& Elderfield H., An intensity ratio calibration method for the accurate determination of $\mathrm{Mg} / \mathrm{Ca}$ and $\mathrm{Sr} / \mathrm{Ca}$ of marine carbonates by ICP-AES, Geochemistry, Geophysics, Geosystems, 3, doi. 10.1029/2001GC000169, 2002.

[16] Cahyarini, S.Y., Zinke, J., Troelstra, S., Coral Sr/Ca-based Sea Surface Temperature and Air Temperature variability across the Seribu Islands and Jakarta bay, Indonesia. in prep, 2009.

[17] Shen, C.C., Lee, T., Yun chen, C., Ho Wang, C., Feng Dai, C. \& An Li , L., The calibration of $\mathrm{D}(\mathrm{Sr} / \mathrm{Ca})$ versus sea surface temperature relationship for Porites corals, Geochimica et Cosmochimica Acta, 60(20), 3849-3858, 1996.

[18] Alibert C., Kinsley, L., Fallon, S.J., McCulloch, M.T., Berkelmans, R., and McAllister, F., Source of trace element variability in Great Barrier Reef corals affected by the Burdekin flood plumes, Geochimica et Cosmochimica Acta, 67(2), 231-246, 2003.

[19] Mitsuguchi, T., Matsumoto, E. \& Uchida T., $\mathrm{Mg} / \mathrm{Ca}$ and $\mathrm{Sr} / \mathrm{Ca}$ ratios of Porites coral skeleton: Evaluation of the effect of skeletal growth rate, Coral Reefs, doi: 10.1007/s00338-003-0326-1, 2003.

[20] Suharsono, Condition of coral reef resource in Indonesia, Jurnal Pesisir dan Lautan, 1(2), 44-52, 1998. 